SILVA, GO; PEREIRA, AS; CARVALHO, ADF; AZEVEDO, FQ. 2019. Yield, frying quality, plant vigor, and maturity of potato clones. Horticultura Brasileira 37: 095-100. DOI - http://dx.doi.org/10.1590/S0102-053620190115

\title{
Yield, frying quality, plant vigor, and maturity of potato clones
} Giovani Olegario da Silva ${ }^{1} \mathbb{D}$; Arione da S Pereira ${ }^{2} \mathbb{D}$; Agnaldo DF Carvalho ${ }^{3} \mathbb{D}$; Fernanda Q Azevedo $^{2} \mathbb{D}$

${ }^{1}$ Embrapa Hortaliças/SIN, Canoinhas-SC, Brazil; giovani.olegario@embrapa.br; ${ }^{2}$ Embrapa Clima Temperado, Pelotas-RS, Brazil; arione. pereira@embrapa.br; fernanda.azevedo@embrapa.br; ${ }^{3}$ Embrapa Hortaliças, Brasília-DF, Brazil; agnaldo.carvalho@embrapa.br

\begin{abstract}
The objective of this research was to evaluate advanced potato clones for tuber yield, frying quality, plant vigor, and maturity, grown from minituber seeds, and to assess correlations between these traits. Eight advanced potato clones of Embrapa Potato Breeding Program (F11-09-03, F05-11-03, F54-11-06, F141-11-01, C2718-12-09, C2718-24-09, C2743-09-09, and CL308) and three commercial cultivars (Agata, Asterix and BRSIPR Bel) were evaluated. Experiments were carried out in autumn 2017, in Canoinhas-SC and Pelotas-RS. A randomized complete block design with four replicates was used. We used tuber seeds type IV (minibubers)". We evaluated plant vigor, maturity, yield and number of marketable tubers, yield and number of total tubers, average tuber weight, specific gravity, and frying color. Individual and joint variance analyses revealed significant differences $(\mathrm{p}<0.05)$ among genotypes for all traits at both locations. The GxE (genotype $\mathrm{x}$ environment) interaction was significant for all traits. For the two locations together, clones F0511-03, C2718-12-09, C2718-24-09 and the control cultivar BRSIPR Bel showed higher marketable tuber yields. The first two clones also showed tubers with high average tuber weight. Clone F54-11-06 showed the later maturity at both locations. Regarding the frying quality characteristics, only clone F141-11-01 showed a pattern comparable to that of the control cultivar Asterix. Also, clones with higher plant vigor had higher tuber yield, but late maturity. Frying quality traits were not correlated between them and among other traits.
\end{abstract}

Keywords: Solanum tuberosum, breeding, selection.

\section{RESUMO}

Rendimento de tubérculos, qualidade de fritura, vigor de plantas e ciclo vegetativo de clones de batata

O objetivo com o presente trabalho foi avaliar caracteres de rendimento de tubérculos, de qualidade de fritura, vigor de planta e ciclo vegetativo de clones de batata cultivados a partir de minitubérculos, e a correlação entre essas características. Foram avaliados oito clones avançados em fase de desenvolvimento pelo programa de melhoramento da Embrapa (F11-09-03, F05-11-03, F54-11-06, F141-11-01, C2718-12-09, C2718-24-09, C2743-09-09 e CL308) e três cultivares comerciais (Agata, Asterix e BRSIPR Bel). Os experimentos foram realizados no outono de 2017, em CanoinhasSC e Pelotas-RS. O delineamento experimental foi em blocos casualizados com quatro repetições. Foram utilizados tubérculossemente tipo IV (minitubérculos). Avaliou-se o vigor vegetativo das plantas, ciclo vegetativo, massa e número de tubérculos comerciais, massa e número total de tubérculos, massa média de tubérculos, peso específico e cor de fritura. As análises de variância individual e conjunta revelaram diferenças significativas $(p<0,05)$ entre os genótipos para todos os caracteres nos dois locais. A interação GxA (genótipo $\mathrm{x}$ ambiente) foi significativa para todos os caracteres. Para os dois locais conjuntamente, os clones F05-11-03, C2718-12-09, C2718-24-09 e a cultivar testemunha BRSIPR Bel apresentaram os maiores rendimentos de tubérculos comerciais. Os dois primeiros clones também apresentaram tubérculos com elevada massa média. O clone F54-11-06 apresentou-se como o mais tardio, em ambos os locais. Quanto à qualidade de fritura, apenas o clone F141-11-01 teve padrão comparável à testemunha 'Asterix' no conjunto de caracteres e locais. Ainda, clones com maior vigor apresentaram maior rendimento de tubérculos, porém ciclo vegetativo mais tardio. Os caracteres de qualidade de fritura não apresentaram correlações significativas entre eles ou com outras características.

Palavras-chave: Solanum tuberosum, fitomelhoramento, seleção.

Received on August, 22, 2018; accepted on January 23, 2019

$\mathrm{T}$ he development of national potato cultivars adapted to the Brazilian growing conditions and resistant to the main diseases that affect the crop is the most viable alternative to increase yield and grower's profitability (Gadum et al., 2003).

Several are the traits considered for selection by potato breeders. Among them, much importance is given to the tuber yield, aiming at greater profitability for producers (Silva et al., 2014). However, it is very important in the selection process to find the balance between tuber number and tuber size. Potato plants producing high tuber number usually have smaller tubers (Silva et al., 2012). Both, the tuber number and the tuber size, directly influence the marketable yield (Silva et al., 2006).

Plant vigor is another important trait for the development of new cultivars, but, careful selection is necessary for this trait, because clones with very vigorous plants usually have late maturity (Bradshaw et al., 2004). Silva et al. (2007), evaluating potato segregating families, verified mediummagnitude correlations between plant vigor and plant size, tuber number and yield, indicating that more vigorous plants produce larger tubers, with higher 
numbers, and higher yields.

About maturity, for both temperate and tropical regions, late maturing cultivars ( $>130$ days) present higher yields than early cultivars (Silva \& Pinto, 2005; Rodrigues et al., 2009). However, growers prefer earlier cultivars (Rodrigues et al., 2009), since they allow greater number and use with other crops throughout the year, shorter exposure time of plants to eventual weather, lower risk of diseases and pests, and lower demand for irrigation. In addition, the earliness allows to adjust the harvest of the crop to the advantageous quotation of the product in the market. Thus, early maturity is a very relevant trait in potato breeding programs, but should be associated with other traits, such as tuber yield (Silva et al., 2014).

The potato tuber may be sold to the fresh market or to the processing industry. In the fresh market, consumers give great importance to the tuber appearance, whereas in the industry, processors require traits that confer frying quality, such as high specific gravity, low reducing sugar content and absence of physiological disorders. Specific gravity is an important trait, because it is directly related to the dry matter content of the tubers. Higher specific gravity provides higher processing yield, less fat absorption, better texture without affecting the taste of the final product. On the other hand, lower sugar content prevents the darkening of the processed products, which compromises the appearance and flavor of the fried product (Silva et al., 2014).

The challenge of meeting these requirements requires high efficiency of breeding programs to identify superior genotypes. Therefore, procedures that provide information to assist in choosing the best selection strategy are important. As an example, one can cite the use of correlation analyzes between traits to better understand the genetic relationships between them.

Being potato vegetatively propagated, it accumulates various diseases, such as viruses, bacteria, fungi and nematodes, with the sequence of crop generations. To avoid the influence of these pathogens on selection, clones can be submitted to the meristem culture in laboratory, followed by production of minitubers in a greenhouse. These minitubers are individuals genetically identical to the plant that originated them, they are clones, but with smaller tuber size, because they are generated from small seedlings. In order to speed up the breeding process and thus gain a season compared to the strategy of multiplying this material to produced larger sized tubers, one can use these small tubers of high phytosanitary quality for planting the first yield trials.

Although minituber seeds produce lower yield than conventional tuber seeds, with less experimental precision, several authors (Teixeira et al., 2010; Masarirambi et al., 2012; Silva et al., 2017) have reported that the selection for yield traits is efficient. The lower experimental precision can be attributed to smaller stem number produced by the minituber seeds, which have fewer buds. Tuber number is correlated with stem number (Feltran \& Lemos, 2008), therefore, it is expected that when there is a smaller number of stems, a variation of this number reflects a percentage of variation between plants much larger than the variation of that number in plants with more stems coming from larger tubers. Greater variation is also expected among plants of the same clone for tuber yield traits.

The objective of this work was to evaluate tuber yield, frying quality, plant vigor and maturity of potato clones grown from minituber seeds, and to calculate correlations between these traits.

\section{MATERIAL AND METHODS}

The experiments were carried ou in Canoinhas-SC (2610'38'S, 50²3'24”' $\mathrm{W}, 839 \mathrm{~m}$ altitude) and Pelotas-RS (31 $1^{\circ} 52^{\prime} 00^{\prime}$ 'S , 52 $21^{\prime} 24^{\prime \prime} \mathrm{W}, 50 \mathrm{~m}$ altitude) on autumn 2017. Eight potato clones of the Embrapa breeding program (F11-09-03, F05-11-03, F54-11-06, F141-11-01, C2718-12-09, C2718-2409, C2743-09-09, and CL308) and three commercial cultivars (Agata, Asterix and BRSIPR Bel) were evaluated.
'Agata' has yellow skinned tubers and is destined for table market. 'Asterix' presents red skinned tubers destined for both table market and processing (French fries). 'BRSIPR Bel' has yellow skinned tubers and is destined for processing (chips and shoestrings).

The minituber seeds were planted out in field experiments on February 7, 2017 and March 14, 2017, in Canoinhas and Pelotas, respectively. A randomized complete block design with four replicates was used. Plots consisted of two $3.5 \mathrm{~m}$ rows, spaced $0.75 \mathrm{~m}$ apart with 10 plants on each row. Type IV tuber seeds (minitubers, 23-30 mm diameter) were used, which had been stored for eight months in a cold room $\left(3.5 \pm 0.5^{\circ} \mathrm{C}\right)$. Cultural and phytosanitary pratices followed the recommendations for the regions (Silva \& Lopes, 2017). Fertilization was carried out in the planting row at the dose of $3 \mathrm{t} \mathrm{ha}^{-1}$ of the formula NPK 05-20-10 in Pelotas, and the same dosage of formula 04-14-08 in Canoinhas.

Fifty days after planting, after checking plant emergency, plant vigor was visually assessed, assigning scores from 1 to 5 ( $1=$ high vigor, $2=$ mediumhigh vigor, $3=$ medium vigor, $4=$ medium-low vigor, and $5=$ low vigor) (Silva et al., 2007).

Maturity was assessed visually 95 days after planting, assigning scores from 1 to 9 ( $1=$ late, $9=$ early) (Silva $e t$ al., 2012).

After plant senescence, 100 days after planting, plants were harvested. The following yield traits were evaluated: marketable tuber diameter ( $>45 \mathrm{~mm}$ ), number per plot; total tuber number per plot; marketable tuber yield $\left(\mathrm{kg} \mathrm{plot} \mathrm{t}^{-1}\right)$; total tuber yield $\left(\mathrm{kg} \mathrm{plot}^{-1}\right)$ and the average tuber weight ( $\mathrm{g}_{\text {tuber }}{ }^{-1}$ ) obtained from the division of total tuber yield by the total tuber number. The specific gravity was assessed using $3.630 \mathrm{~g}$ marketable tuber samples per plot, with the Snack Food Association hydrometer (Silva et al., 2012). The frying color was assessed using three marketable and healthy tubers per plot. Fifteen slices were cut $2.0 \mathrm{~mm}$ thick, which were fried in vegetable fat, at the initial temperature of $180^{\circ} \mathrm{C}$ until the bubbling ceased. Notes 1 to $9(1=$ 
dark, 9= light) were attributed (Silva et al., 2016).

Data of tuber yield were converted to $\mathrm{tha}^{-1}$ and data of tuber number into number ha-1/1000 tubers.

The data of two locations were submitted to joint and individual analysis of variance, and grouping means by the Scott-Knott test, at 5\% probability using the Genes statistical software (Cruz, 2016).

The magnitudes of the correlation coefficients were classified as Carvalho et al. (2004): $\mathrm{r}=0$ (null); $0<|\mathrm{r}|<0.30$ (weak); $0.30<|\mathrm{r}|<0.60$ (average); $0.60<$ $|\mathrm{r}|<0.90$ (strong); $0.90<|\mathrm{r}|<1$ (very strong) and $|\mathrm{r}|=1$ (perfect).

\section{RESULTS AND DISCUSSION}

Analysis of variance of the data from the two experiments together and of each individual location revealed significant differences $(\mathrm{p}<0.05)$ among genotypes for all traits at both locations (data not shown). The genotype $\mathrm{x}$ environment interaction (GxE) was significant for all traits.
In average, for Pelotas, the coefficient of variation (CVe) for yield traits was $21.34 \%$, which is close to that for Canoinhas $(21.66 \%)$. For these same traits, and also using minituber seeds, Silva et al. (2017) reported similar values.

Although some traits showed relatively high $\mathrm{CVe}$, such as the marketable tuber yield $(33.36 \%$ in Pelotas) and marketable tuber number (36.12\% in Canoinhas), most traits presented a relation between the genetic coefficient of variation and environmental coefficient of variation $(\mathrm{CVg} / \mathrm{CVe})$ close to or greater than unity (Tables 1 and 2). This preponderance of genetic variance over environmental variance suggests that the selection process would be efficient for these traits. Average tuber weight in Pelotas and frying color in Canoinhas were the exceptions, and for these traits caution is suggested in drawing conclusions about the performance of the genotypes. About the highest values verified for marketable tuber number and marketable tuber yield, the results are in agreement with Silva et al. (2012). These are quantitative traits, suffering greater environmental influence when compared with others traits controlled by few genes.

The marketable tuber yield, which is the most important tuber yield trait, for genotypes ranged in average from 9.48 to $12.82 \mathrm{t} \mathrm{ha}^{-1}$, at both sites; however, in Canoinhas, one of the clones produced 27.26 t ha $^{-1}$ (Tables 1 and 2). It is known that the use of tuber seeds smaller than a certain minimum size results in lower yields. However, comparing with the use of larger tuber seeds, the ranking of the genotypes tends to remain similar (Silva et al., 2017), which confers confidence to carry out selection.

In relation to marketable tuber yield traits, having as selection criterion the higher average genotypes for the marketable tuber number and marketable tuber yield together, it is verified that clones F05-11-03, C2718-12-09 and C2718-24-09, and the control cultivar BRSIPR Bel were the most productive genotypes at both locations (Tables 1 and 2). Besides those, the clones F54-11-06, F11-09-03 and CL308 also showed good yield in Canoinhas, both grouped with intermediate averages of marketable tuber yield.

Table 1. Means, coefficients of environmental variation (CVe), relation of coefficient of genetic to environmental coefficient of variation $(\mathrm{CVg} / \mathrm{CVe})$ and mean of tuber yield traits, frying quality, plant vigor and vine maturity of 11 potato genotypes evaluated in autumn 2017 in Pelotas-RS, Brazil, using seed tubers type IV (minitubers). Canoinhas, Embrapa, 2017.

\begin{tabular}{lccccccccc}
\hline Genotype & MTY & MTN & TTY & TTN & ATW & Vigor & Mat & SG & Cor \\
\hline BRSIPR Bel & $15.92 \mathrm{a}^{2}$ & $170.95 \mathrm{a}$ & $18.82 \mathrm{a}$ & $262.38 \mathrm{a}$ & $70.77 \mathrm{a}$ & $2.00 \mathrm{~b}$ & $7.50 \mathrm{a}$ & $1.077 \mathrm{a}$ & $8.25 \mathrm{a}$ \\
F05-11-03 & $14.58 \mathrm{a}$ & $119.05 \mathrm{~b}$ & $16.32 \mathrm{a}$ & $186.19 \mathrm{~b}$ & $85.91 \mathrm{a}$ & $2.75 \mathrm{~b}$ & $7.25 \mathrm{a}$ & $1.071 \mathrm{c}$ & $5.50 \mathrm{~b}$ \\
C2718-12-09 & $12.84 \mathrm{a}$ & $130.95 \mathrm{~b}$ & $15.71 \mathrm{a}$ & $219.53 \mathrm{~b}$ & $71.64 \mathrm{a}$ & $3.25 \mathrm{~b}$ & $7.75 \mathrm{a}$ & $1.073 \mathrm{~b}$ & $5.25 \mathrm{~b}$ \\
C2718-24-09 & $12.22 \mathrm{a}$ & $123.34 \mathrm{~b}$ & $14.14 \mathrm{a}$ & $191.91 \mathrm{~b}$ & $73.78 \mathrm{a}$ & $3.00 \mathrm{~b}$ & $7.50 \mathrm{a}$ & $1.074 \mathrm{~b}$ & $4.00 \mathrm{~b}$ \\
F11-09-03 & $9.43 \mathrm{~b}$ & $86.19 \mathrm{c}$ & $12.98 \mathrm{a}$ & $185.24 \mathrm{~b}$ & $69.72 \mathrm{a}$ & $2.50 \mathrm{~b}$ & $6.75 \mathrm{a}$ & $1.067 \mathrm{~d}$ & $3.63 \mathrm{~b}$ \\
F54-11-06 & $8.67 \mathrm{~b}$ & $74.76 \mathrm{c}$ & $10.79 \mathrm{~b}$ & $135.24 \mathrm{c}$ & $79.54 \mathrm{a}$ & $3.50 \mathrm{a}$ & $5.00 \mathrm{~b}$ & $1.078 \mathrm{a}$ & $4.63 \mathrm{~b}$ \\
C2743-09-09 & $6.90 \mathrm{~b}$ & $70.95 \mathrm{c}$ & $8.72 \mathrm{~b}$ & $138.57 \mathrm{c}$ & $63.80 \mathrm{~b}$ & $4.00 \mathrm{a}$ & $7.25 \mathrm{a}$ & $1.072 \mathrm{c}$ & $5.00 \mathrm{~b}$ \\
F141-11-01 & $4.85 \mathrm{~b}$ & $53.81 \mathrm{~d}$ & $7.41 \mathrm{~b}$ & $123.33 \mathrm{c}$ & $60.11 \mathrm{~b}$ & $4.25 \mathrm{a}$ & $7.50 \mathrm{a}$ & $1.077 \mathrm{a}$ & $3.75 \mathrm{~b}$ \\
CL308 & $3.34 \mathrm{~b}$ & $34.77 \mathrm{~d}$ & $6.05 \mathrm{~b}$ & $96.19 \mathrm{c}$ & $63.68 \mathrm{~b}$ & $5.00 \mathrm{a}$ & $7.00 \mathrm{a}$ & $1.062 \mathrm{e}$ & $6.50 \mathrm{~b}$ \\
Agata & $6.11 \mathrm{~b}$ & $71.43 \mathrm{c}$ & $10.28 \mathrm{~b}$ & $202.86 \mathrm{~b}$ & $50.95 \mathrm{~b}$ & $4.00 \mathrm{a}$ & $7.75 \mathrm{a}$ & $1.061 \mathrm{e}$ & $4.25 \mathrm{~b}$ \\
Asterix & $9.38 \mathrm{~b}$ & $85.24 \mathrm{c}$ & $13.11 \mathrm{a}$ & $205.72 \mathrm{~b}$ & $63.78 \mathrm{~b}$ & $2.00 \mathrm{~b}$ & $7.00 \mathrm{a}$ & $1.077 \mathrm{a}$ & $4.63 \mathrm{~b}$ \\
\hline Mean & 9.48 & 92.85 & 12.21 & 177.01 & 68.51 & 3.29 & 7.11 & 1.072 & 4.96 \\
CVe & 33.36 & 21.14 & 25.16 & 14.02 & 15.89 & 20.46 & 7.07 & 0.14 & 24.41 \\
CVg/CVe & 1.18 & 1.94 & 1.19 & 1.89 & 0.72 & 0.94 & 1.44 & 4.02 & 1.01 \\
\hline
\end{tabular}

$\mathrm{MTY}=$ marketable tuber yield $\left(\mathrm{t} \mathrm{ha}^{-1}\right) \mathrm{MTN}=$ marketable tuber number per ha $\mathrm{a}^{-1} / 1000 ; \mathrm{TTY}=$ total tuber yield $\left(\mathrm{t}\right.$ ha $\left.{ }^{-1}\right)$; TTN $=$ total tuber number per ha-1/1000; ATW= average tuber weight $\left(\mathrm{g}_{\text {tuber }}{ }^{-1}\right)$; Vigor= plant vigor (notes $1=$ high, $2=$ medium-high, $3=$ medium, $4=$ medium-low, $5=$ low); Mat $=$ maturity (notes from $1=$ late to $9=$ early); $\mathrm{SG}=$ specific gravity; Cor $=$ chip color (notes from $1=$ dark to $9=$ light). ${ }^{2} \mathrm{Means}$ followed by same letters in each column belong to the same group, Scott-Knott test, $5 \%$ probability. 
Taking this same criterion for the total tuber number and total tuber yield, clones F11-09-03, F05-11-03, C271812-09 and C2718-24-09, and the control cultivars Asterix and BRSIPR Bel were the most productive genotypes at both locations (Tables 1 and 2). Clones CL308 and F54-11-06 also presented good total tuber yield in Pelotas.
In spite of the significant $\mathrm{GxE}$ interaction for all traits, unlike the other tuber yield traits, for the average tuber weight, that is directly related with tuber size, there was less coincidence of genotype ranking as superior in the two locations (Tables 1 and 2). Only clones F05-11-03, C2718-12-09 and F54-11-06 belonged to the upper group in the two locations, that is, they had larger tubers in Pelotas and Canoinhas; the first two clones also showed good yield, and clone F54-11-06 showed large but lower tuber number, suggesting a negative relation between tuber number and average tuber weight, at least for this clone.

Concerning plant vigor, the less

Table 2. Means, coefficients of experimental variation (CVe), relation of coefficient of genetic to environmental coefficient of variation $(\mathrm{CVg} / \mathrm{CVe})$ and mean of tuber yield traits, frying quality, plant vigor and vine maturity of 11 potato genotypes evaluated in autumn 2017 in Canoinhas-SC, Brazil, using seed tubers type IV (minitubers). Canoinhas, Embrapa, 2017.

\begin{tabular}{lccccccccc}
\hline Genotype & MTY & MTN & TTY & TTN & ATW & Vigor & Mat & SG & Cor \\
\hline BRSIPR Bel & $18.66 \mathrm{~b}^{2}$ & $91.13 \mathrm{a}$ & $38.77 \mathrm{a}$ & $304.43 \mathrm{a}$ & $130.29 \mathrm{~b}$ & $2.50 \mathrm{c}$ & $1.50 \mathrm{f}$ & $1.073 \mathrm{c}$ & $6.75 \mathrm{a}$ \\
F05-11-03 & $27.26 \mathrm{a}$ & $109.17 \mathrm{a}$ & $38.76 \mathrm{a}$ & $236.55 \mathrm{~b}$ & $164.48 \mathrm{a}$ & $1.50 \mathrm{~d}$ & $3.50 \mathrm{e}$ & $1.066 \mathrm{~d}$ & $6.25 \mathrm{a}$ \\
C2718-12-09 & $17.35 \mathrm{~b}$ & $60.62 \mathrm{~b}$ & $34.76 \mathrm{a}$ & $239.45 \mathrm{~b}$ & $145.77 \mathrm{a}$ & $4.50 \mathrm{a}$ & $6.00 \mathrm{~d}$ & $1.067 \mathrm{~d}$ & $6.25 \mathrm{a}$ \\
C2718-24-09 & $13.49 \mathrm{~b}$ & $61.61 \mathrm{~b}$ & $27.19 \mathrm{~b}$ & $218.54 \mathrm{~b}$ & $124.95 \mathrm{~b}$ & $5.00 \mathrm{a}$ & $7.50 \mathrm{~b}$ & $1.077 \mathrm{~b}$ & $5.00 \mathrm{~b}$ \\
F11-09-03 & $15.80 \mathrm{~b}$ & $64.92 \mathrm{~b}$ & $31.59 \mathrm{~b}$ & $229.84 \mathrm{~b}$ & $138.08 \mathrm{~b}$ & $1.50 \mathrm{~d}$ & $4.00 \mathrm{e}$ & $1.061 \mathrm{e}$ & $6.25 \mathrm{a}$ \\
F54-11-06 & $18.19 \mathrm{~b}$ & $65.56 \mathrm{~b}$ & $29.83 \mathrm{~b}$ & $178.59 \mathrm{c}$ & $166.69 \mathrm{a}$ & $1.50 \mathrm{~d}$ & $1.00 \mathrm{f}$ & $1.067 \mathrm{~d}$ & $5.75 \mathrm{a}$ \\
C2743-09-09 & $5.20 \mathrm{c}$ & $23.00 \mathrm{c}$ & $12.57 \mathrm{~d}$ & $91.86 \mathrm{~d}$ & $147.66 \mathrm{a}$ & $5.00 \mathrm{a}$ & $7.00 \mathrm{c}$ & $1.081 \mathrm{a}$ & $5.50 \mathrm{a}$ \\
F141-11-01 & $5.01 \mathrm{c}$ & $18.12 \mathrm{c}$ & $13.96 \mathrm{~d}$ & $122.61 \mathrm{~d}$ & $112.55 \mathrm{c}$ & $5.00 \mathrm{a}$ & $7.50 \mathrm{~b}$ & $1.073 \mathrm{c}$ & $7.00 \mathrm{a}$ \\
CL308 & $16.27 \mathrm{~b}$ & $60.97 \mathrm{~b}$ & $31.05 \mathrm{~b}$ & $202.30 \mathrm{~b}$ & $153.97 \mathrm{a}$ & $3.50 \mathrm{~b}$ & $1.00 \mathrm{f}$ & $1.061 \mathrm{e}$ & $3.25 \mathrm{c}$ \\
Agata & $2.28 \mathrm{c}$ & $6.45 \mathrm{c}$ & $20.87 \mathrm{c}$ & $312.00 \mathrm{a}$ & $67.23 \mathrm{~d}$ & $5.00 \mathrm{a}$ & $8.50 \mathrm{a}$ & $1.065 \mathrm{~d}$ & $5.75 \mathrm{a}$ \\
Asterix & $1.50 \mathrm{c}$ & $3.39 \mathrm{c}$ & $24.91 \mathrm{~b}$ & $240.00 \mathrm{~b}$ & $104.50 \mathrm{c}$ & $4.00 \mathrm{~b}$ & $7.00 \mathrm{c}$ & $1.071 \mathrm{c}$ & $7.50 \mathrm{a}$ \\
\hline Mean & 12.82 & 51.36 & 27.66 & 216.01 & 132.38 & 3.54 & 4.95 & 1.070 & 5.93 \\
CVe & 27.57 & 36.12 & 13.95 & 16.41 & 13.65 & 12.61 & 10.54 & 0.16 & 20.01 \\
CVg/CVe & 2.26 & 1.78 & 2.26 & 1.81 & 1.54 & 3.37 & 5.43 & 3.54 & 0.81 \\
\hline
\end{tabular}

$\mathrm{MTY}=$ marketable tuber yield $\left(\mathrm{t} \mathrm{ha}^{-1}\right)$; MTN= marketable tuber number per ha ${ }^{-1} / 1000$; TTY $=$ total tuber yield $\left(\mathrm{t}\right.$ ha $\left.{ }^{-1}\right)$; TNT $=$ total number of tubers per ha-1/1000; ATW= average tuber weight $\left(\mathrm{g}\right.$ tuber $\left.{ }^{-1}\right)$; Vigor= plant vigor (notes $1=$ high, $2=$ medium-high, $3=$ medium, $4=$ mediumlow, $5=$ low); Mat= maturity (notes from $1=$ late to $9=$ early); $\mathrm{SG}=$ specific gravity; $\mathrm{Cor}=$ chip color (notes from $1=$ dark to $9=$ light). ${ }^{2} \mathrm{Means}$ followed by same letters in each column belong to the same group, Scott-Knott test, $5 \%$ probability.

Table 3. Genotypic correlations between characters of tuber yield, frying quality, vegetative cycle and plant vigor of the evaluation of eleven potato genotypes grown in Canoinhas-SC (lower diagonal) and Pelotas-RS (upper diagonal), Brazil, in autumn 2017, using type IV seed tubers (minitubers). Canoinhas, Embrapa, 2017.

\begin{tabular}{llllllllll}
\hline & MTY & MTC & TTN & TTY & ATW & Vigor & Mat & SG & Cor \\
\hline MTY & & $0.98^{*}$ & $0.87^{*}$ & $0.98^{*}$ & 0.50 & $-0.80^{*}$ & 0.32 & 0.42 & -0.57 \\
MTN & $0.98^{*}$ & & $0.82^{*}$ & $0.98^{*}$ & $0.65^{*}$ & $-0.90^{*}$ & 0.21 & 0.46 & -0.52 \\
TTN & 0.24 & 0.20 & & $0.92^{*}$ & 0.11 & $-0.87^{*}$ & 0.46 & 0.23 & -0.39 \\
TTY & $0.87^{*}$ & $0.86^{*}$ & $0.63^{*}$ & & 0.50 & $-0.96^{*}$ & 0.27 & 0.39 & -0.50 \\
ATW & $0.77^{*}$ & $0.80^{*}$ & -0.38 & 0.47 & & -0.50 & -0.46 & 0.46 & -0.27 \\
Vigor & $-0.76^{*}$ & $-0.76^{*}$ & -0.23 & $-0.72^{*}$ & $-0.62^{*}$ & & $0.78^{*}$ & -0.52 & 0.14 \\
Mat & $-0.73^{*}$ & $-0.74^{*}$ & -0.11 & $-0.68^{*}$ & $-0.73^{*}$ & $0.80^{*}$ & & -0.26 & -0.13 \\
SG & -0.26 & -0.36 & -0.46 & -0.50 & -0.09 & 0.52 & 0.44 & & -0.02 \\
Cor & -0.26 & -0.27 & 0.20 & -0.04 & -0.43 & -0.10 & 0.36 & 0.27 & \\
\hline
\end{tabular}

$\mathrm{MTY}=$ marketable tuber yield $\left(\mathrm{t} \mathrm{ha}^{-1}\right) ; \mathrm{MTN}=$ marketable tuber number per $\mathrm{ha}^{-1} / 1000 ; \mathrm{TTY}=$ total tuber yield $\left(\mathrm{t}\right.$ ha $\left.{ }^{-1}\right)$; TTN $=$ total tuber number per ha-1/1000; ATW= average tuber weight $\left(\mathrm{g} \mathrm{tuber}^{-1}\right)$; Vigor= plant vigor (notes $1=$ high, $2=$ medium-high, $3=$ medium, $4=$ medium-low, $5=$ low); Mat= maturity (notes from $1=$ late to $9=$ early); $\mathrm{SG}=$ specific gravity; Cor= chip color (notes from $1=$ dark to $9=$ light). $*$ Significant at $5 \%$ probability, t test. 
vigorous genotypes, that is, genotypes with higher notes for the two locations were F141-11-01, C2743-09-09 and the control cultivar Agata (Tables 1 and 2). On the other hand, clones presenting higher vigor for the two locations, were F11-09-03 and F05-11-03, whereas control cultivars Asterix and BRSIPR Bel presented higher vigor than Agata. In addition, it can be observed that, in general, the lower vigorous clones also presented lower tuber yield, and the opposite for those of higher vigor.

The maturity was another trait that showed high variation between locations (Tables 1 and 2). In Pelotas, the most late clone was F54-11-06, while the others were similar to each other and to the controls. This clone was also very late in Canoinhas, along with clone CL308 and cultivar BRSIPR Bel. The earliest genotypes in Canoinhas were the control cultivar Agata, followed by clones C2718-24-09 and F141-11-01.

Regarding the frying quality traits, specific gravity and frying color, the clones were compared to controls Asterix and BRSIPR Bel, which are mainly destined for processing, mainly the first, which is widely used for the national French frying processing industry. In the Embrapa Potato Breeding Program, the selection criterion is that the clones be superior or at least equivalent to this control in the frying quality traits and that they have other superior traits such as tuber yield and tolerance to diseases, among others. By this criterion, the selected clones for specific gravity would be F54-11-06 and F141-11-01 for Pelotas, and C2743-09-09, C271824-09 and F141-11-01 for Canoinhas. For frying color, none of the clones was compared to the control cultivar BRSIPR Bel, which presented the clearest chips in Pelotas, but all did not differ from Asterix. Except clones C2718-24-09 and CL308, all others did not differ from the control cultivars in Canoinhas. Thus, in the two locations together, considering maximum specific gravity, only clone F141-11-01 stood out together with the two control processing cultivars. For frying color, with this same criterion, most clones (F11-0903, F05-11-03, F54-11-06, F141-1101, C2718-12-09, and C2743-09-09) presented good performance in both locations, with a similar frying color to the control Asterix.

To elucidate relationships between the traits evaluated in this work, a genotype correlation analysis was performed (Table 3). Considering only correlations observed in both locations, in order to have greater reliability in the results, a positive correlation is verified of marketable tuber number and marketable tuber yield with total tuber yield and negative with the plant vigor. This is in agreement with previous observation that clones with higher vigor present higher tuber yield. The relation with plant vigor and tuber yield was also verified for total tuber yield, and is in accordance to the results of Silva et al. (2007), who also observed higher yields of tubers for genotypes with more vigorous plants.

The plant vigor was also positively correlated with maturity, indicating that more vigorous clones are also late maturing, agreeing with Bradshaw et al. (2004).

As expected, higher marketable tuber yield was produced by higher average tuber weight clones, that is, clones with larger tubers.

In relation to average tuber weight and tuber number, as previously mentioned in the case of clone F5411-06, in this study no significant correlation was observed with total tuber number, indicating that this relation was not a rule for this set of genotypes.

The frying quality traits did not show significant correlations between them or with other traits. Bisognin et al. (2008) also found no significant associations between yield traits and frying quality traits. Likewise, Pereira \& Campos (1999) concluded that there was no strong association between reducing sugar content and tuber yield, reporting negative and nonsignificant correlations. Rodrigues \& Pereira (2003), based on low correlations between the quality and yield traits, concluded that the selection for the frying color as for dry matter content would affect little the tuber yield of the plants of the population sample of selected clones. Terres et al. (2012) found a correlation of low magnitude (0.19), but significant, between the highest total tuber yield and the darker frying color, while Pereira et al. (1994) found a negative correlation between better frying color and higher total yield and tuber size. Simon et al. (2009) reported a correlation of low magnitude ( 0.34 ) between highest total tuber yield and higher specific gravity in a study of 12 potato clones. All these estimates indicate that this association is dependent on the set of clones evaluated, but that, when it occurs, is of low magnitude.

In light of the results of these experiments, it can be stated that clones F05-11-03, C2718-12-09, and C2718-24-09 have high yield potential, comparable to the control cultivar BRSIPR Bel. The first two clones also have high average tuber weight. Clone F54-11-06 is late maturity. Only clone F141-11-01 has frying quality comparable to the control cultivar Asterix. Clones with high vigor show high tuber yield and late maturity. Frying quality traits are not significantly correlated between them, nor with other traits.

\section{REFERENCES}

BISOGNIN, DA; COSTA, LC; ANDRIOLO, JL; MÜLLER, DR; BANDINELLI, MG. 2008. Produtividade e qualidade de tubérculos de clones de batata. Ciência e Natura 30: 43-56.

BRADSHAW, JE; PANDE, B; BRYAN, GJ; HACKETT, CA; MCLEAN, K; STEWART, HE. 2004. Interval mapping of quantitative trait loci for resistance to late blight [Phytophthora infestans (Mont.) de Bary], height and maturity in a tetraploid population of potato (Solanum tuberosum subsp. tuberosum). Genetics 168: 983-995.

CARVALHO, FIF; LORENCETTI, C; BENIN, G. 2004. Estimativas e implicações da correlação no melhoramento vegetal. Pelotas: UFPel. $142 \mathrm{p}$.

CRUZ, CD. 2016. Genes Software-extended and integrated with the R, Matlab and Selegen. Acta Scientiarum Agronomy 38: 547-552.

FELTRAN, JC; LEMOS, LB. 2008. Características agronômicas e distúrbios fisiológicos em cultivares de batata.Cientifica 33: 106-113.

GADUM, J; PINTO, CABP; RIOS, MCD. 2003. Desempenho agronômico e reação de clones de batata (Solanum tuberosum L.) ao PVY. Ciência e Agrotecnologia 27: 1484-1492.

MASARIRAMBI, MT; MANDISODZA, FC; MASHINGAIDZE, AB; BHEBHE, E. 2012. Influence of plant population and seed tuber size on growth and yield components of potato (Solanum tuberosum L.). International Journal 
of Agriculture and Biology 14: 545-549.

PEREIRA, AS; TAI, GCC; YADA, RY; TARN, TR; SOUZA-MACHADO, V; COFFIN, RH. 1994. Effect of selection for chips colour on some economic traits of potatoes. Plant Breeding 113: 312-317.

PEREIRA, AS; CAMPOS, A. 1999. Sugar content in potato (Solanum tuberosum L.) genotypes. Ciência Rural 29: 13-16.

RODRIGUES, AFS; PEREIRA, AS. 2003. Correlações inter e intragerações e herdabilidade de cor de chips, matéria seca e produção em batata. Pesquisa Agropecuária Brasileira 38: 599-604.

RODRIGUES, GB; PINTO, CAB; BENITES, FRG; MELO, DS. 2009. Seleção para duração do ciclo vegetativo em batata e relação com a produtividade de tubérculos. Horticultura Brasileira 27: 280-285.

SIMON, GA; PINTO, CABP; LAMBERT, ES; ANDREU, MA. 2009. Seleção de clones de batata resistentes à pinta preta e tolerantes ao calor. Ceres 56: 31-37.
SILVA, LAS; PINTO, CABP. 2005. Duration of the growth cycle and the yield potential of potato genotypes. Crop Breeding and Applied Biotechnology 5: 20-28.

SILVA, GO; SOUZA, VQ; PEREIRA, AS; CARVALHO, FIF; FRITSCHE-NETO, R. 2006. Early generation selection for tuber appearance affects potato yield components. Crop Breeding and Applied Biotechnology 6: 73-78.

SILVA, GO; PEREIRA, A; SOUZA, VQ; CARVALHO, FIF; FRITSCHE NETO, R. 2007. Correlações entre caracteres de aparência e rendimento e análise de trilha para aparência de batata. Bragantia 66: 381-388.

SILVA, GO; CASTRO, CM; TERRES, LR; ROHR, A; SUINAGA, FA; PEREIRA, AS. 2012. Desempenho agronômico de clones elite de batata. Horticultura Brasileira 30: 557-560.

SILVA, GO; PEREIRA, AS; CARVALHO, ADF. 2014. Seleção de clones de batata para fritura com base em índices de seleção. Ceres 61: 941-947.
SILVA, GO; PEREIRA, ADS; AZEVEDO, FQ; CARVALHO, ADF. 2016. Avaliação de clones de batata para caracteres de rendimento e qualidade de fritura.Revista Latinoamericana de la Papa 20: 37-44.

SILVA, GO; PEREIRA, AS; CARVALHO, ADF; AZEVEDO, FQ; PONIJALEKI, RS. 2017. Rendimento de tubérculos de clones avançados de batata. Revista Latinoamericana de la Papa 21: 1-7.

SILVA, GO; LOPES, CA. 2017. Sistema de produção da batata. Brasília: Embrapa. Available at https://www.spo.cnptia.embrapa. br/temas-publicados. Accessed November 16, 2017.

TEIXEIRA, AL; SILVA, CA; PEIXOUTO, LS; LEPRE, AL. 2010. Eficiência na emergência e produtividade dos diferentes tipos de batatasemente. Scientia Agraria 11: 215-220.

TERRES, LR; NEY, VG; CERIOLI, MF; PEREIRA, AS; TREPTOW, RO. 2012. Respostas esperadas de seleção para cor de fritura em quatro populações híbridas de batata. Horticultura Brasileira 30: 300-303. 